\title{
Meaning-making and crime drama: The case of criminology students
}

\begin{abstract}
Criminology as a discipline maintains an ambivalent attitude toward mass media. Following from Clifford and White's (2017) call for a more nuanced approach to media criminology, the first section of the article contextualises the present study by outlining the uneasy relationship between mainstream criminology and crime drama. The second section explores themes that arose during research that invited criminal justice students to create an outline for a television crime series that they would enjoy watching themselves. The experience of creating and talking about their crime fictions prompted the participants to reflect on aspects of their own lives in some detail, but relatively little on crime per se. Crime drama, including their own creations, provided the participants with an anchor to talk broadly about subjectivities and identities. The piece concludes with observations on the place of emotional engagement when consumers reflect on crime drama.
\end{abstract}




\section{Meaning-making and crime drama: The case of criminology students}

\section{Introduction: Criminologists and mass media}

The term 'popular criminology' was popularised by media criminologist Nicole Rafter (2007) to refer to the ways in which people develop their views about crime and justice. She noted that crime entertainment was central to these public understandings, and argued that: 'The two types of criminology, popular and academic, complement one another, each contributing in its own way to understandings of crime' (2007: 415). Thus, by strong implication, criminologists could not afford to treat mass media representations of crime as simply inferior entities. Interestingly, in view of Rafter's emphasis on complementarity, even the most empathetic surveys of media criminology suggest that, in the main, popular criminology and crime media in particular, continue to be seen by criminologists as marginal to the real business of scholarly criminology (Kohm, 2017; Wakeman, 2016).

The cautious approach to scholarly analysis of fictional crime confirms Lam's (2014) observation that academic criminologists are more interested in 'corrective criticism' than in understanding the complexities of crime media production and consumption, or in understanding the ways crime drama is absorbed into the lives of audiences. Rather, corrective criticism tends 'to treat popular cultural representations as first and foremost inaccurate representations about crime or as questionable matters of fact' (p. 171).

Media criminology, or the study of the ways in which crime media saturate and inform our lives and, in turn, the ways we interact with media, remains a relatively underdeveloped field of scholarship in Australia. Some topics are receiving increasing attention; for example, work here has tended to concentrate on the criminological implications of the uses and abuses of social media (Goldsmith, 2015; Lee and Crofts, 2015; Lee and McGovern, 2014; Salter 2017). Internationally, there has been modest growth in introductory texts informed by 
theorising from both criminology and media studies (e.g., Clifford and White, 2017; Jewkes, 2015; Marsh and Melville, 2014; Moore 2014; Surette, 2015). On the other hand, and probably indicative of the silences in the criminological literature, there has been an upsurge in studies of crime fiction, particularly crime drama (Colbran, 2014; Evans, 2009; Lam, 2014; McCaw, 2011; Piper, 2015; Turnbull, 2014). Few of these scholars would identify themselves as media criminologists; most are drawn from the fields of communications and cultural and media studies. They are cognizant of the criticisms levelled by mainstream criminologists at crime drama. For example, Turnbull (2014: 10) notes: 'For some critics, especially those who approach the genre from a criminological perspective informed by statistics about the "real" world of crime, the television crime drama is to be condemned for its distortions.'

There are signs of rapprochement in Australia. Clifford and White (2017), while acknowledging the common 'tendency towards criminological parochialism', advocate a reorientation toward interdisciplinary partnerships in media criminology research: 'While the provincialism evident within the practice of media criminology may not be problematic in itself, we argue that there is much to be gained - in terms of richer, deeper, reflexive, nuanced and applied forms of analyses - from a more deliberate coupling and convergence of empirical knowledge, conceptual approaches and research methodologies specific to each of these [criminology, media studies, and communications] disciplinary fields' (Clifford and White, 2017: 18-19). The present study aims to contribute to this broader, nuanced conception of media criminology by exploring the ways criminology students construct personal and professional meanings and identity markers from television crime drama.

An irony to note in passing is that the discipline of law, a foundational discipline of criminology (along with sociology and psychology), enjoys a healthy scholarship in 'popular jurisprudence' (MacNeil, 2007), or the ways in which law is represented and thought about in popular culture (for recent Australian contributions, see de Zwart et al, 2015; Sharp and 
Leiboff, 2016). It seems that law and media studies share a comfortable coexistence because law is essentially a textual discipline in theory and practice (Robson et al, 2014). As de Zwart et al (2015: xiii) note, legal scholars and practitioners live with narratives whereby professional and interpersonal 'skills are developed and enhanced by telling and analysing stories about ourselves, our fears, hopes, struggles and victories'. On the other hand, criminology as a social science, and one that in some quarters sees itself increasingly as 'crime science' (Loader and Sparks, 2012), appears less comfortable with popular narratives, and remains especially suspicious of 'fictions'.

This is not to deny that fictional crime has long been incorporated, often in a relatively narrow fashion, as a pedagogical tool for teaching criminological concepts and theory (e.g., Crawford, 1999; Kopak and Sefiha, 2015; Oliver, 2011; Rafter and Brown, 2011; Rockell, 2009; Rothe and Collins, 2013). But there is often a clear note of ambivalence and caution sounded about the use of such fictions. For example, Kopak and Sefiha (2015: 109-10) warned educators against 'reifying stereotypes' through the 'voyeuristic appeal' of violence found in crime entertainment. Crawford (1999) recounted the way he used fictional police films as a way of exploring the multiple representations of policing and police officers over time, but he felt the principal objective was to correct 'misconceptions' and 'misunderstandings': 'Many citizens, my new students particularly, hold many preconceived notions about the nature and operations of law enforcement, [but through film] I am able to point out where many of these misconceptions of police work originate' (p. 57). Seen in this light, Rockell's (2009: 75) comment seems particularly apposite when she notes (approvingly) that addressing crime fiction with criminal justice students typically constitutes 'teaching by stealth', or the attempt to educate by deconstructing aspects of their preconceptions and 'sensational interests' (see Robbers, 2007, below). 
Thus, while some criminologists have a research and teaching interest in the ways crime and media intersect, much less attention has been paid to the ways in which undergraduates in criminology and criminal justice engage with and consume crime in factual and fictional media. This is an intriguing observation since many of these graduates will become criminal justice practitioners in the very areas that constitute the staples of mediatised crime. Of those studies that have been conducted (e.g. Barthe et al, 2013; Robbers, 2007) many are based on surveys of large samples of college students in the US. These quantitative, correlational studies seem intent on uncovering supposed media-induced misunderstandings and misconceptions about crime and criminal justice. For example, Robbers (2007) concluded that criminal justice students had excessive interests in 'sensational media', a finding said to align their entertainment interests with those of 'offender populations'. According to this research, criminal justice students shared interests with convicted offenders in crime shows that emphasised violence, thrill seeking, and 'sadism'. Criminal justice educators were advised to take keener interest in the viewing preferences of their students, presumably with the intention of countering the detrimental effects of 'sensational' entertainment.

Similarly, Barthe et al (2013) claimed that television crime series were responsible for misinforming undergraduates about aspects of the criminal justice system. Particular concern was expressed about possible frustrations as students discovered that their career aspirations did not match mass-mediated expectations. The 'unreality' of crime series was singled out for special criticism: 'While televised portrayals of the criminal justice system have always approximated real life without being exact, they have in more recent years become further removed from real life, resulting in blatantly inaccurate depictions that may negatively impact public perceptions' (pp. 24-25). Like the Robbers (2007) study, educators were tasked with 'undo[ing] the damage wrought by the entertainment media, whose first intention is to 
entertain, not educate, and [where] factual elements may be freely altered to increase entertainment value' (Barthe et al, 2013: 25).

What is troubling theoretically about these overseas examples of mainstream criminological research into student uses of crime media is that they largely reflect a perspective called the 'hypodermic syringe model'. According to this view, 'the relationship between media and audiences is conceived as a mechanistic and unsophisticated process, by which media “inject" values, ideas and information directly into a passive receiver producing direct and unmediated "effects", (Jewkes, 2015: 16-17). That is, they exhibit a simplistic relational model that has been dismissed as inadequate in media and communications research for the past 30 years or more. That crime media trade in distortion and misinformation is a view also commonly impressed upon Australian criminology students. Their textbooks perpetuate the media-as-enemy perspective. For example, Wood (2015) concludes: 'It [media] is regularly driven by forces other than public interest or objectivity in terms of how it (mis)represents crime, criminals, victims and the criminal justice system'. Again, as with the US studies, criminologists are tasked with informing criminal justice students and professionals about 'the ways in which the media obfuscate or even wilfully distort our knowledge of who is involved or impacted by crime' (pp. 18-19).

\section{The current study}

The present study set out to advocate for the importance of researching crime drama consumption. The research did not attempt to identify particular effects of television drama, especially in view of critiques of the notion of direct, cumulative and measurable effects (Gauntlett, 2005). Kitzinger (2004: 167-8) points to the chameleon nature of audience research, noting that 'explicating the audience-text relation is a chimera, which can only ever be apprehended partially, [...] audience is a shifting concept'. Doyle (2006) has similarly 
suggested that the fixation of criminologists on the (detrimental) effects of mass media, or the attempt to pin down the 'chimera', condemned them to repetitive research and theorising on crime media: 'Sagas of crime and punishment in the media may seem eternally recurrent; we [criminologists] must be careful to avoid a similar eternal recurrence of problematic analyses of them' (2006: 875). The current study contributes empirically to our knowledge of the way crime entertainment is consumed (and worked on) by people to construct their views about the world, and especially about themselves and their identities. A suggestive theoretical model was drawn from the sociology/anthropology of 'media practice' (Bird, 2010; Couldry, 2004). From this perspective, media are seen to anchor the development of broader ideas and perceptions and concerns that may not obviously be the province of crime media per se. That is, studies of media practice explore the ways in which media consumers, in this case criminology students, incorporate crime drama as a resource to think about constellations of concerns in their lives.

Similarly, Ellis (1999) argues that even drama, a form of television that appears to move towards a conclusion or finality in the sense of providing some resolution to the narrative, still provides plenty of opportunities along the way for viewers to digress, to work through and talk through aspects of their own lives and broader cultural concerns. Viewers, he notes, may psychologically desire resolution of the story, and drama endeavours 'to provide a sense of ending', but our lives tend 'towards uncertainty and openness': ‘... television's distinctive contribution to the modern age [is that it constitutes] a relatively safe area in which uncertainty can be entertained (and can be entertaining) ... it seems that television's contribution to our ability to live with uncertainty is crucial' (Ellis, 1999: 64).

The present research differed from the US studies cited earlier which are quantitative and correlational in methodology (Barthe et al, 2013; Robbers, 2007). Rather, given the ubiquity of crime drama and the fact that the participants were criminal justice students, the aim was 
to explore the ways the participants described their interactions with crime media, and the kinds of associations they made between fictional crime and other aspects of their lives. The study asked the participants to design a crime series that they themselves would want to watch and then investigated with them why they would watch it. In this way, the participants were both producers and consumers.

\section{Method and participants}

The method was borrowed in part from Bird (2003: 86-117). Her anthropological study incorporated recordings of participants working in groups to develop a television series featuring portrayals of Native Americans. In Bird's (2003) study, more emphasis was placed on the planning stages of participants' projects. In the present study, greater emphasis was placed on the follow-up interview (see below) because the researcher primarily wanted to talk to students about the ways they used crime drama in practice. An invitation was sent to criminology and criminal justice undergraduates in an Australian teaching/research university asking for volunteers to participate in a project on crime television. Ethics clearance was granted by the university (CCJ/19/15/HREC).

Ten students expressed interest. They were asked to invite a partner to join them in the project, someone with whom they felt comfortable working. The partners did not need to be criminology students, nor did they even have to be students. The pairs were people who in various ways shared media consumption, and thus the project acknowledged the sociality of television consumption (Gauntlett and Hill, 1999). The majority of Australians (86.0\%) consume free-to-air and subscription channels partly by way of in-home sets (OzTAM, 2017) and they consume it live, at the time of broadcast. Even with more solitary viewing, irrespective of reception technology, people still talk about their viewing with family, friends or workmates. Thus, consumption of crime drama remains largely a shared activity. 
The research consisted of two phases. In the first, the participants (in pairs) were asked to design the outline for a television series that they would want to watch regularly. The only stipulation was that the series was a 'fictional' crime program. The planning meeting between the pair was audio recorded and a summary sheet completed. The researcher was not present during the planning meeting. The audio of the planning session was transcribed. The summary sheet asked for a brief description of the planned series, main characters, the plot of the first episode, why the participants themselves would want to watch their program, and why they thought others might be drawn to their series. Participants were free to draw upon any television series with which they were familiar.

In the second phase, following review of the transcripts and audios, the researcher met with each pair to discuss their series. This second activity seemed particularly important because there was no assumption that crime media 'influences' (if any) could be conveniently read off the participants' summaries from the first phase. In fact, according to Gauntlett (2007: 193), it is unlikely, at least on the surface, that people think their sense of self is influenced much by 'entertainment' unless, as in the present study, they are asked to reflect upon their consumption of fictional texts. This may be so, but perhaps there are more occasions prompting us to reflect on, if not actually talk about, the role of entertainment media in our lives and relationships than Gauntlett allows. Again, the interviews were recorded and transcribed. Participants who completed both phases were given a $\$ 30$ gift voucher as a token of appreciation for their time. As the semester moved into a busy period, two pairs did not complete the first phase and a further two did not complete the second phase. Thus, data were obtained from six pairs (twelve participants). Analysis of the data drew upon the approach advocated by Hollway and Jefferson (2013). Here the attempt was made to develop a holistic understanding (and researcher interpretation) of what the pairs saw as important/meaningful, rather than attempting standard thematic analyses based on highly specific coding schedules. 
Participants were encouraged to make their own associations between those elements that they saw as important in the project. However, transcripts were still coded broadly to identify what seemed to be the major concerns to which participants kept returning. Some coding also allowed the researcher to locate examples of themes that participants were developing.

The dozen participants comprised three males and nine females who were enrolled across different year levels of their three-year degree in criminology and criminal justice. None had ever taken courses (subjects) in media studies. Half were young and had come to the degree straight from secondary school, while the other half were mature students in their thirties and early forties. Five of the volunteers chose a fellow student in the criminology program as their partners, and one chose her flatmate who was doing a science degree at a different university. The recordings and transcripts indicated that the participants worked together amicably, fairly readily coming to agreement on the content and direction they wished their series to take. The participants' names have been changed in the paper. Quotations from the participants' transcripts are indicated by a transcript number T1-T6 (see Table 1) followed by transcript page number (eg, T3: 22). Both phases of the project, the participants planning their series and subsequent interviews, occurred in 2016.

\section{TABLE 1 ABOUT HERE.}

\section{Three cases}

The first three cases in Table 1 will be discussed to demonstrate the ways the participants connected their comments on their series, and their viewing preferences, with aspects of their own lived experience. These three cases have been prioritised in Table 1 and in the following 
analysis because they seem to more fully illustrate the ways viewers incorporate crime drama as a resource for 'working-through' their lives, as noted earlier by Ellis (1999), although features from the other cases are included occasionally. In particular, discussing their creations with the researcher seemed to constitute a bridge between emotional responses and broader reflective and critical comments on their fictions. The emotionality of our connections with crime drama, and its centrality to broader reflection on our lives, are addressed in the final section of the paper.

\section{Tara and Mike ('Life in Pink and Blue')}

Tara and Mike's series concerned transgender equality in a state police service. They derived their idea partly from popular culture and television sources: Caitlyn Jenner's gender transition documented in I am Cait, and the 'awesome transgender' hairdresser in Orange is the New Black. They saw their series as 'risky', but one that in their view 'present[ed] a solid grounding for the revolution Australia needs in diverse sexualities, the sort of thing office people around the cooler talk about, who watch these types of shows' (T1: 11). However, in the second phase of the research the transgender focus tended to recede, replaced by concerns about corruption in political life and the homogenising of Australian culture. With their series turning more to political machinations, it came as little surprise that their favourite program was House of Cards. They admired Kevin Spacey's character, based not on moral approval, but because the series confirmed their own conclusions about the way unbridled political ambition will inevitably triumph over oppositional timidity.

Tara: He's the bad guy you love. You want him to win. Not because he's a nice person but because he's fought tooth and nail for every single thing he has.

Mike: So that's why you kind of want to love him, because he's smarter than [the other characters]. He had this plan. He executed it. He got what he wanted. (T1: 22) 
When participants made comparisons with American series they did so usually to indicate particular aspects that they did not want their own series to feature. Yet, most of the crime drama that participants watched were American series. Australian or British series were rarely mentioned as sources of entertainment or pleasure. Tara and Mike associated Americanisation with a characteristic they called 'excessive dramatization'. On the Melbourne-based gangland series Underbelly, Mike said:

I don't really believe that somebody walks in with a gun and makes a quippy remark and then shoots a person. Then goes and has a drug fuelled binge for three days with prostitutes and stuff. They dramatise it to the point where it's Americanised in that Vegas, nasty, glitzy, gangster type thing which we probably don't really have so much here. (T1: 19)

It is worth staying with Tara and Mike's series for a moment because it illustrates the way emergent themes swirled around each other, touching off associations of ideas, with the participants' commentary feeding back into views and feelings about their own lives. The pair reflected on a recent student society trip to the police academy where it seemed that 'the cadets [recruits] were all cut from the same cloth, they were all of a certain height and they all interacted in a very non-verbal way' $(\mathrm{T} 1: 8,25)$. Tara mused that this may only have been appearances and wondered how different the persons were 'under the uniform'. The notion of delving below appearances was obviously important to their transgender series. Tara said the primary message of their series was 'follow your heart and step outside of your comfort zone, mix with people who are different' (T1: 12).

There is an intersection in the comments of this pair between their current feelings of isolation in the university, their favourite crime drama viewing, and their own imagined series which captures feelings of not belonging. They are mature students still early in their 
academic program, but with considerable life experience behind them. However, they both feel like outsiders. University has not offered a sense of community and involvement. They have observed, according to their transcript, that students seem not to interact in class, and that outside of class students and academic staff have little contact. Both want to be achievers, but don't want to meet conformist expectations to be successful, and both expressed reservations about absorption into bland futures. They use the example of Mulder from one of their favourite shows The X-Files as someone who achieves success without appearing to compromise: 'He's an underdog, a kind of outsider and the machine [the FBI] needs to keep reining him in, until he becomes an integral part of the machine without anybody realising' (T1:27). Thus, the pair designed a hypothetical crime series about a transgender police officer, an outsider in a politically divided police service, a series that Tara was certain her father would not watch, because he would have to accept 'that there is someone else so different [from you] who could [also] be standing in front of you protecting you' (T1: 24). Much of the discussion with Mike and Tara about their production kept returning to their feelings of separation and difference from other students.

\section{Marge and Evelyn ('Snapped')}

Marge and Evelyn had known each other through their degree, but while both had encountered domestic/family violence, neither knew much about the other's experiences until planning their series. They were insistent that even without the Inquiry into domestic violence in Queensland (Bryce, 2015) they would still have chosen domestic/family violence as the basis for their series. Talking together about their experiences in their planning session, they said, helped them re-affirm that they had moved on from the past and now felt 'neutral' about former violent partners or family: 'You just get over it, you don't care anymore, you're not peeved off anymore [...] you just accept that the [former partner] is a crap person and that's it' (T2: 12). Nonetheless, one of them had mentioned 'hate' on a couple of occasions during 
the follow-up interview, before modifying it to 'neutral'. Evelyn noted that planning their series was a 'therapy session' for both.

Evelyn: Because the thoughts were gone until we started doing this [laughs] then it's like, oh yeah. So we started - I think we started telling our stories and that's really where the concept came from. [...] Because we know each other, we've known each other since first year, so we just talk heaps. But it's like, I'll tell a story and she's like yeah, yeah and then she'll tell me a story kind of thing. That actually developed more of our story and then that's when we started recording. Talk about [a] therapy session. (T2: 12, 16)

Both of them stressed their television interests lay with 'real life stuff', by which they meant documentaries on the cable crime channel, when time allowed for viewing. In fact, they seemed surprised that the researcher expressed only limited interest in 'true crime' shows. Both saw their documentary viewing as a resource for their studies. Marge and Evelyn had difficulty relating to fiction programs watched by fellow students. To an extent, they might have been echoing Mike and Tara's sense of separateness on campus, perhaps a common experience for many mature age students. However, these two women were well-advanced in their program, and engaged in student activities, so in this case they were offering another perspective on separateness, revolving around the different uses/pleasures criminal justice students find in crime television.

They commented, perhaps drolly, that while they once used to watch crime drama, the criminology degree had 'ruined [their] TV watching experiences, except for Dexter' (T2: 2930). In fact, three of the pairs - all women - mentioned Dexter, which was the most cited crime series among participants and, like the others, Evelyn said she did not condone vigilante violence, except on the small screen. She claimed that it was the only fiction series 
that she enjoyed because she liked 'gory stuff', but added: 'Look, I would never - I would never do the stuff he does [but] he's balancing the scales of justice and that's what I like' (T2: 25). The paper returns to the participants' 'uses' of Dexter later in the discussion.

\section{Sheena and Liza ('5 Knives')}

Sheena and Liza acknowledged that their respective disciplines (criminology and science) influence their preferred viewing. But also as flatmates, these different viewing pleasures shaped their sense of themselves and each other domestically. Throughout their interview the pair teased and bounced ideas off each other, sounding each other out about the meanings of their respective viewing preferences, no doubt much like their domestic exchanges. They agreed that they even have a different appreciation of crime humour, with Sheena enjoying dark humour, which the scientific Liza finds 'silly'. She mentioned the recent mystery/comedy Scream Queens as her example of misplaced humour. The somewhat dour Liza could not find much humour in crime television, even that labelled entertainment.

Sheena and Liza also referred to Dexter to clarify points about their own revenge/vigilante series. Sheena observed that she could understand the thinking of the vigilante character, but that she could still distance herself from 'exaggerated portrayals'. However, the pair moved quickly to discuss victimisation, which seemed for them to be more relevant or important than vigilantism. In response to a question about how it was that women can watch fictional crime where women are brutalized, as happens in the first episode of their own series, Liza observed 'I know males can be victims too but I guess [the rape and killing of a woman] puts crime into perspective and says that it's not just theory, that it actually occurs in reality, this is something that can happen to anyone' (T3: 22). This was perhaps another gentle dig at Sheena's persona of 'theoretical' criminologist in the pair's friendship. They were aware that crime media may portray victims as enticing their fate because of 'reckless' lifestyles or 
careless behaviours, but neither participant felt drawn to these mass-mediated cautionary tales (Moore, 2009). As young women, the pair had obviously discussed the possibility of victimisation, but Sheena added: 'I don't relate to the victims ever. I would never see myself as being a victim' (T3: 26). However, when asked to nominate a character worthy of admiration, she identified Lisbeth Salander from the 'Millennium Trilogy', a fictional character in whom the extremes of both victim and avenger coalesce, and thus the conversation returned to aspects of the avenger/vigilante:

Sheena: I don't know. It's really hard for a woman. I would say Salander because she's such a strong woman but then you think about everything she has gone through that's made her a strong woman and I wouldn't want to go near that. Yes, for me that's her. She's my hero. She's awesome.

Liza: [Laughs]

Sheena: She is. She's like just - yeah. Even though she's the biggest victim she won't let herself be the victim. She keeps going with it. She's so strong willed. (T3: 34)

\section{Challenging the criminological criticisms}

Three emerging themes challenge, or at least qualify, the mainstream criminological misgivings about crime drama noted at the outset, offering a more nuanced view of the way consumers, in this case criminal justice students, understand and incorporate crime fictions into their lives.

\section{$\underline{\text { Realism and misrepresentation }}$}

Criminological critiques of crime drama censure the apparent lack of authenticity to the 'real world' of crime and justice, which is said to induce audience misunderstandings of the field of criminal justice (e.g. Barthe et al, 2013). All of the participants in the present study 
understood that they were engaged in producing fiction and that their fictions did not have to be rationalised or explained away as 'not real'. They assumed their hypothetical audience understood the 'rules' of consuming fictional crime texts. When Cindy ('Intertwined') expressed concern that she and her partner might not watch their own crime story because it was 'not realistic', Steve's response was: 'People watch lots of shows that aren't realistic. At the end of the day most of the crime shows are unrealistic I feel' (T4: 9), to which she replied simply, 'yeah', and neither of them expressed further concerns about 'realism'. Peter and Philip ('HIT: Brisbane') were initially preoccupied with portraying realistically the day-today procedures of policing, but quickly realised that their fondness for accuracy was likely to result in tedious television. Silverstone (1994) noted that, central to the ongoing construction of self, media consumers recognise 'the boundaries between fantasy and reality' because the 'practicalities of everyday life' necessitate maintaining such distinctions. In the current study, production and consumption of crime fiction were often talked about in terms of the participants' personal life, including emotional responses, but they clearly recognised the (admittedly porous) boundaries between their fictions and everyday life.

Indeed, Colbran (2014: 224) noted that in the world of crime television 'authentic reality' tends not to attract large audiences. Rather, the aim of good crime drama is to be realistic enough to engage viewers and then to assist those 'who are so inclined' to think through dilemmas of crime and justice, a process that Evans (2009: 166) calls the fictional probing of 'fault lines', or looking behind various representations of good and evil, and potentially disrupting taken-for-granted views.

\section{Consuming the 'sensational'}

Robbers (2007) concluded that criminal justice undergraduates exhibit 'sensational' viewing interests, but then one assumes that most criminology students would have some interest in 
crime drama. Moreover, correlational research (such as Barthe et al, 2013; Robbers, 2007) cannot pinpoint and expand upon the ways audiences incorporate their preferred viewing to engage in moral/ethical reflections on aspects of their lives, as in the case of our participants. Such reflection may arise by way of 'identification' with (or recognition of) fictional characters. Bird (2003) noted in her study of online fan sites that emotional connections with favourite characters and series generated ethical/moral exchanges between fans. She concluded that 'for most people, most of the time, whether contemplating a great novel or a TV show, the formal, the moral and the emotional are not separated, but (if effective) work together to create a sense of pleasure and aesthetic appreciation' (2003: 139).

We return to this point about the cohesion of emotion and reflection in the final section of the paper. For media criminologists at least, "part of the appeal of writing scholarly treatments of crime [fictions] may be that they permit more passion and moral positioning than most criminological subjects' (Jewkes, 2015: 217). What may unsettle many other criminologists is the very fact that crime fictions confront 'questions concerning the nature of good and evil [and] ethically they take passionate moral positions that would be out of place in academic analyses (Rafter, 2007, quoted in Jewkes, 2015: 217). Indeed, much existing criminological research often does not deal at all well with emotive aspects of crime and criminality. The participants in the present study held few reservations about connecting their crime dramas with their broader emotional lives.

The often mentioned example of Dexter does not, of course, signify approval of vigilantism, nor point to any particular 'sensationalist' leanings. The three pairs of participants who referred to Dexter (the character) were all women. Dexter as a complex drama features multilayered story lines and themes, and vigilantism in the form of revenge killings is only one of these themes, albeit a stark and memorable one. While some studies suggest that women perceive in Dexter an alternative criminal masculinity, one that does not victimise 
women (Arellano, 2015; Nurse, 2012), all of the participants disavowed personal support for 'real world' vigilantism. Sheena and Lisa moved from talking about vigilantism to victimisation and female heroism, and thus they illustrate the mingling of possible responses elicited by one crime drama. A comment cited earlier from Evelyn suggests that her liking for Dexter was partly based on the show's exploration of the limitations and injustices of the criminal justice system ('he's balancing the scales of justice and that's what I like'). It seemed as though her consumption of Dexter helped her (a criminal justice student) to think through - or at least balance - the tensions and ambiguities of a system in which she wanted to work. The attraction for the participants constituted a 'viewing affinity' (Piper, 2009). They expressed some sympathy in understanding Dexter's motives, and even expressed a kind of televisual allegiance between themselves as women and a fictional vigilante whose mother had been murdered.

\section{$\underline{\text { Crime drama and professional identities }}$}

Indeed, a particularly interesting finding is that the participants did not reflect upon crime in society to any great extent. Nor did they take the opportunity to talk about their career plans as these might have related to their viewing preferences. There is little indication in the findings that crime dramas were leading the participants astray in terms of misinforming them about criminal justice philosophies and practices, a core criticism of Barthe et al (2013). Unlike Sharp's $(2005-6 ; 2011)$ research with law undergraduates, which focused on their television-mediated perceptions of lawyers and the world of lawyering, the present research explored more broadly the place of crime fiction in the everyday lives of the participants. Sheena and Lisa certainly talked about their respective disciplines, especially in the context of viewing preferences, but this tended to be couched in terms of their domestic arrangements and friendship rather than career plans. It may be that in another research context, perhaps addressing specifically the relationship between viewing preferences and careers, our 
participants might have had more to say about contemporary crime, but not during the current research. The participants touched on career plans, but not as much as we might expect, given both the ubiquity of crime drama as well as the strong vocational orientations of criminology students (Tontodonato, 2006; Wimshurst and Allard, 2007).

The four women whose series dealt with domestic violence had no intention of working professionally in that field, including Marge who was interested in policing, and realised she may have to respond to domestic/family violence. Peter and Philip ('HIT: Brisbane') commented on career interests more than the others. Both were young and in the first year of the degree, and one of them was clearly more interested in law than criminology as he was aiming to transfer to law school. His favourite series was Suits but he believed, by way of a parent who worked in a law firm, that television law tended to emphasise glamour rather than 'real life'. In fact, Peter and Philip's case tended to run counter to the other five pairs. The two were more concerned, at least initially, about the place of 'realism', and they talked more about vocational interests. They had some difficulty conceptualising the 'message' of their series for audiences. Indeed, they had trouble with the concept of 'message', seeing it literally as some kind of concluding 'voice over' that warns viewers to protect their online personal details, or to be careful in railway car parks late at night.

\section{Crime drama, emotion and reflection}

In developing their series, the participants drew upon aspects of their lives to construct characters and plots, and they also related their preferred viewing to their lives. They were variously aware of stylistic ways of conveying their themes. Tara and Mike wanted to vary the colour schemes of the office décor according to mood and action; darker colours when police management were plotting, brighter colours when characters were supporting each other to further the reform effort. Tara referred to this production effect as being 'subtly 
loud': 'Much like House of Cards where it's - you know, when he's in trouble the weather starts to storm and stuff that reflects his mind' (T1: 11).

This combination of personal, thematic and stylistic awareness is reminiscent of the 'framing schema' developed by Liebes and Katz $(1990 ; 1991)$ which theorised two main consumer responses to television series. The first was called 'referential' and was characterised by emotional responses to characters and plots. That is, viewer appreciation of a program reflected their 'emotional investment'. A second type of response was termed 'critical' and signalled the viewer's 'cognitive investment', arising from an increased understanding of such features as genre characteristics and of production styles and techniques. In fact, Liebes and Katz were careful to add the proviso that television consumers tended not to inhabit solely one of these responsive domains and noted: '[...] the sophisticated viewer should be seen as a commuter between the referential and the critical, and not just one or the other' (1991: 208). Aware of this tendency for audiences to 'commute' between the referential (emotional) and critical (cognitive/thoughtful) responses to television series, Liebes and Katz then added another type of 'critical' response called 'pragmatic criticism' (1990: 125-127; 1991: 216-218), which combined the referential and critical as viewers become increasingly aware of why they respond emotionally to particular series and characters.

While the Liebes and Katz model is part and parcel of media studies theorising, and has seen modification over the years, it is not difficult to see how some conception of a developmental hierarchy in consumer responses also underpins criminological critiques of crime entertainment, critiques that are replete with references to 'emotional manipulation', 'misinformation', and 'sensationalist appeal' (recall the critiques of Barthe et al, 2013; Robbers, 2007). Mainstream criminologists by and large remain professionally wary of the emotional attractions and entanglements of crime fictions. Accordingly, consumers (in the current study, criminology students) are seen to inhabit a rather limited emotional and 
uncritical domain in their engagement with crime media. Fewer, it is implied, progress to a critical domain which apparently affords consumers a more sophisticated awareness of their own 'manipulation'. While there have been developments in audience response theorising in both media studies and media sociology/anthropology, scholars across disciplines (depending on their research agenda) have found the demarcation between two responsive modes (referential versus critical, or emotional versus reflective) an enticing theoretical and analytical tool, while at times acknowledging the model's limitations.

For example, Sharp (2016), a cultural legal studies scholar, used this responsive model to explore the development of punitive attitudes among television audiences, including law students. She argued that audiences respond emotively (referentially) to portrayals of crime and victimisation, and thus tend to adopt punitive stances toward offenders in 'real life'. However, some of her participants also attempted to grapple with the ways 'messages' are framed, and were said to move toward a critical mode of reception, recognising their own textual manipulation. Sharp (2016: 55) acknowledged Liebes and Katz's notion of responsive commuting back and forth, but her study still emphasised the developmental progression from emotional/affective to cognitive/reflective viewing responses.

Yet there seems no obvious or convincing reason, at least based on the present study, for treating the affective domain as subservient to the cognitive. Our participants moved back and forth between emotional and reflective positions as they considered personal (mainly) and professional aspects of their crime productions and viewing preferences. In line with media practice theorising (Bird, 2010; Couldry, 2004) they engaged with crime fictions (including their own) emotionally while simultaneously (it seems) reflecting on personal, cultural, and relational aspects of their social environments. There seems no reason to assume that they - and other audiences - do not engage in similar seesawing or bridging responses when consuming crime drama in daily life, beyond the research situation. Other scholars have 
recognised the salience of emotions for integrating audience responses, and not simply as building blocks to some higher critical domain. We have already noted Bird's (2003) study of online fan sites showing that emotional connections with favourite characters and series generated ethical/moral exchanges between fans. Bartsch (2012), drawing on a psychological needs and gratifications perspective, arrived at a similar conclusion about the centrality of emotions to reflectivity and connections with our fellow media consumers. She concluded that '[crime] entertainment research could profit from expanding its current focus on rewarding aspects of moods and emotions per se [and move to explore] the interplay of emotion, cognition, and interpersonal communication' (2012: 297).

\section{Conclusions}

The participants linked the research activity of creating a crime drama with reflections about themselves and the way their own viewing might contribute to their sense of themselves. At times they talked about career directions, but not much, and they did not linger on thoughts about crime to any great extent. Rather, their comments, based on their fictional creations, ranged over personal matters and the current state of their lives, their aspirations, aspects of popular culture, and reflections on crime drama and their viewing preferences. It was apparent that some participants had probably not thought a great deal about the ways crime drama becomes part of their daily lives, and there is no reason why they should have pondered this relationship prior to the research project. Other participants certainly took the opportunity to talk about their lives. It seems reasonable to assume that many different prompts, including comments from family, friends and workmates relating to TV crime drama, may encourage us as consumers into reflecting on the connections between crime drama and our sense of self. 
The findings challenge the criminological critiques levelled against crime drama. There was little evidence that participants confused fiction with 'reality'. They remained aware that they were producing crime fictions, and seemingly dismissed thoughts about the necessity to strive for 'authenticity' or to portray the 'actuality' of crime and the criminal justice system, beyond a threshold to establish the credibility of their series. Neither was there evidence of pronounced 'sensational interests'. The majority of the participants were women and/or mature aged students, and thus the roles of biographical and social-structural factors (age, gender) could be further explored. It may be that maturity brings with it a more reflective response to crime drama, based on one's 'ordinary' life experiences; perhaps more of a blurring/integrating of the emotional and reflective. These criminology undergraduates may have some advantages in terms of theoretical and systemic insights, but in everyday life they consume crime television in multiple ways, no doubt like other audiences, again alerting us to the necessity for exploring the complexities and nuances of person/crime text interactions. 


\section{References}

Arellano L (2015) The heroic monster: Dexter, masculinity, and violence. Television \& New Media 16(2): 131-147.

Barthe E, Leone M and Lateano T (2013) Commercializing success: the impact of popular media on the career decisions and perceptual accuracy of criminal justice students. Teaching in Higher Education 18(1): 13-26.

Bartsch A (2012) Emotional gratification in entertainment experience. Why viewers of movies and television series find it rewarding to experience emotions. Media Psychology 15(3): 267-302.

Bird SE (2010) From fan practice to mediated moments: the value of practice theory in the understanding of media audiences. In: Brauchler B and Postill J (eds) Theorising Media and Practice. New York: Berghahn Books, pp. 85-104

Bird SE (2003) The Audience in Everyday Life. New York: Routledge.

Bryce Q (Chairperson) (2015) Not Now, Not Ever: Putting an End to Domestic and Family Violence in Queensland, Queensland Government Printer, www.communities. qld.gov.au (accessed 10 April 2018).

Clifford K and White R (2017) Media and Crime: Content, Context and Consequence. Melbourne: Oxford University Press.

Colbran M (2014) Media Representations of Police and Crime: Shaping the Police Television Drama. Basingstoke, Hampshire, UK: Palgrave, Macmillan .

Couldry N (2004) Theorising media as practice. Social Semiotics 14(2): 115-132. 
Crawford C (1999) Law enforcement and popular movies: Hollywood as a teaching tool in the classroom. Journal of Criminal Justice and Popular Culture 6(2): 46-57.

de Zwart M, Richards B and Le Mire S (eds) (2015) Law and Popular Culture in Australia. Chatswood NSW: LexisNexis Butterworths.

Doyle A (2006) How not to think about crime in the media. Canadian Journal of Criminology and Criminal Justice 48(6): 867-885.

Ellis J (1999) Television as working-through. In: Gripsrud J (ed) Television and Common Knowledge. London: Routledge, pp. 55-70.

Evans M (2009) The Imagination of Evil: Detective Fiction and the Modern World. London: Continuum.

Gauntlett D (2005) Ten things wrong with the media 'effects' model. In: Gauntlett D (ed.) Moving Experiences: Media Effects and Beyond, 2nd edn. London: John Libbey Publishing, pp. 143-152.

Gauntlett D (2007) Creative Explorations: New Approaches to Identities and Audiences. London: Routledge.

Gauntlett D and Hill A (1999) TV Living: Television, Culture and Everyday Life. London: Routledge.

Goldsmith A (2015) Disgracebook Policing: social media and the rise of police indiscretion. Policing \& Society 25(3): 249-67.

Hollway W and Jefferson T (2013) Doing Qualitative Research Differently: A Psychosocial Approach, $2^{\text {nd }}$ edn. London: Sage.

Jewkes Y (2015) Media \& Crime, 3rd edn. London: Sage. 
Kitzinger J (2004) Audience and readership research. In: Dowling J, McQuail D, Schlesinger P and Wartella E (eds) The SAGE Handbook of Media Studies. Thousand Oaks, CA: Sage, pp. 167-181.

Kohm S (2017) Popular criminology. Oxford Research Encyclopedia of Crime, Media, and Popular Culture, DOI: 10.1093/acrefore/9780190264079.013.158

Kopak A and Sefiha O (2015) Becoming badass: teaching Katz's 'Ways of the Badass' using the Breaking Bad television series. Journal of Criminal Justice Education 26(1): 94-114.

Lam A (2014) Making Crime TV: Producing Entertaining Representations of Crime for Television Broadcasts. Abingdon, Oxon: Routledge.

Lee $\mathrm{M}$ and Crofts T (2015) Gender, pressure, coercion and pleasure: untangling motivations for sexting between young people. British Journal of Criminology 55(3): 454-473.

Lee M and McGovern A (2014) Policing and Media: Public Relations, Simulations and Communications. New York: Routledge.

Liebes T and Katz E (1990) The Export of Meaning: Cross-Cultural Readings of Dallas. Cambridge: Polity Press.

Liebes T and Katz E (1991) On the critical abilities of television viewers. In: Seiter E, Borchers H, Kreutzer G and Warth E (eds) Remote Control: Television, Audiences, and Cultural Power. London: Routledge, pp. 204-222.

Loader I and Sparks R (2012) Situating criminology: on the production and consumption of knowledge about crime and justice. In: Maguire M, Morgan R and Reiner R (eds), The Oxford Handbook of Criminology. Oxford: Oxford University Press, pp. 3-38 
MacNeil W (2007) Lex Populi: The Jurisprudence of Popular Culture. Stanford, CA:

Stanford University Press.

Marsh I and Melville G (2014) Crime, Justice and the Media, $2^{\text {nd }}$ edn. London: Routledge.

McCaw N (2011) Adapting Detective Fiction: Crime, Englishness and the TV Detectives, London: Continuum.

Moore S (2009) Cautionary tales: Drug-facilitated sexual assault in the British media. Crime, Media, Culture 5(3): pp. 305-320.

Moore S (2014) Crime and the Media. Basingstoke, UK: Palgrave Macmillan.

Nurse A (2012) Decoding the dark passenger: the serial killer as a force for justice. In:

Robson P and Silbey J (eds), Law and Justice on the Small Screen. Oxford: Hart Publishing, pp. $403-423$

Oliver W (2011) Crime, history, and Hollywood: learning criminal justice history through major motion pictures. Journal of Criminal Justice Education 22(3): 420-439.

OzTAM (2017) Australian Multi-Screen Report. Quarterly reports available at $\underline{\text { www.oztam.com.au }}$

Piper H (2009) 'How long since you were last alive?' Fitz and Tennison ten years on. Screen 50(2): $233-250$.

Piper H (2015) The TV Detective: Voices of Dissent in Contemporary Television. London: LB Taurus.

Rafter N (2007) Crime, film and criminology: recent sex-crime movies. Theoretical Criminology 11(3): 403-420. 
Rafter N. and Brown M (2011) Criminology Goes to the Movies: Crime Theory and Popular Culture. New York: New York University Press.

Robbers M (2007) Crime shows and sensational interests: an exploratory examination of students in criminal justice related majors. Journal of Criminal Justice and Popular Culture 14(4): 344-361.

Robson P, Osborn G and Greenfield S (2014) The impact of film and television on perceptions of law and justice: towards a realisable methodology. In: Wagner A and Sherwin R (eds), Law, Culture and Visual Studies. London: Springer, pp. 1011-1028.

Rockell B (2009) Challenging what they all know: integrating the real/reel world into criminal justice pedagogy. Journal of Criminal Justice Education 20(1): 75-92.

Rothe D and Collins V (2013) Teaching criminological theory: the power of film and music. Critical Criminology 21(2): pp. 227-241.

Salter M (2017) From geek masculinity to Gamergate: the technological rationality of online abuse. Crime, Media, Culture, DOI 10.1177/1741659017690893

Sharp C (2005-6) The 'extreme makeover' effect of law school: students being transformed by stories. Texas Wesleyan Law Review 12(1): 233-50.

Sharp C (2011) 'Represent a murderer ... I'd never do that!' How students use stories to link ethical development and identity construction. In: Robertson M, Corbin L, Tranter K and Bartlett F (eds), The Ethics Project in Legal Education. New York: Routledge, pp. 33-51.

Sharp C (2016) Finding stories of justice in the art of conversation: ethnography in cultural legal studies. In: Sharp C and Leiboff M (eds), pp. 50-67. 
Sharp C and Leiboff M (eds) (2016) Cultural Legal Studies: Law's Popular Cultures and the Metamorphosis of Law. Abingdon, Oxon: Routledge.

Silverstone R (1994) Television and Everyday Life. London: Routledge.

Surette R (2015) Media, Crime and Criminal Justice: Images, Realities, and Policies, $5^{\text {th }}$ edn. Stanford, Connecticut: Cengage Learning.

Tontodonato P (2006) Goals, expectations, and satisfaction of criminal justice majors: implications for faculty, students, and programs. Journal of Criminal Justice Education 17(1): 162-180.

Turnbull S (2014) The TV Crime Drama. Edinburgh: Edinburgh University Press.

Wakeman S (2016) Crime drama as social science fiction. Oxford Research Encyclopedia of Crime, Media, and Popular Culture. DOI: 10.1093/acrefore/9780190264079.103.28

Wimshurst K and Allard T (2007) Criminal justice education, employment destinations, and graduate satisfaction. Australian and New Zealand Journal of Criminology 40 (2): 218-235.

Wood W (2015) Media and crime. In: Hayes H and Prenzler T (eds) An Introduction to Crime and Criminology, 4th edn. Melbourne: Pearson, pp. 3-21 
Table 1. Titles and descriptions of participants' crime drama series.

\begin{tabular}{|c|c|c|}
\hline Participants & Title of series & Description* \\
\hline $\begin{array}{l}\text { Tara (female) } \\
\text { Mike (male) } \\
\text { Transcript } 1 \\
\text { (T1) }\end{array}$ & $\begin{array}{l}\text { Life in Pink and } \\
\text { Blue }\end{array}$ & $\begin{array}{l}\text { A 'stereotypical hyper-masculine senior constable' is } \\
\text { partnered with a young transgender woman constable. } \\
\text { She is assigned to his station following public criticism } \\
\text { over the lack of diversity in Australian police services. } \\
\text { As the story progresses, these two tend to recede and } \\
\text { increasing attention is given to police politics and } \\
\text { 'corruption' within the hierarchy as officers and } \\
\text { management take sides on the issue. }\end{array}$ \\
\hline $\begin{array}{l}\text { Marge (f) } \\
\text { Evelyn (f) }\end{array}$ & Snapped & $\begin{array}{l}\text { The series is about female offending in a household } \\
\text { against a male victim (husband/father). It is a homicide } \\
\text { series which is described as a 'whodunit'. The main } \\
\text { theme is about family violence where the four } \\
\text { daughters have been abused in different ways by both } \\
\text { parents, particularly the father. The killer might be the } \\
\text { mother, or eldest daughter, or both. }\end{array}$ \\
\hline $\begin{array}{l}\text { Sheena (f) } \\
\text { Liza (f) }\end{array}$ & 5 Knives & $\begin{array}{l}\text { Described as 'a dark crime solving drama', based on a } \\
\text { small secret society that solves murders and then } \\
\text { executes the offender. The society comprises people in } \\
\text { everyday jobs and professions, apparently beyond } \\
\text { suspicion. It has been in existence for at least three } \\
\text { generations. The current group of five are the most }\end{array}$ \\
\hline
\end{tabular}




\begin{tabular}{|c|c|c|}
\hline & & recent incarnation. \\
\hline $\begin{array}{l}\text { Steve (m) } \\
\text { Cindy (f) }\end{array}$ & Intertwined & $\begin{array}{l}\text { The show is about an Australian family who relocate } \\
\text { on exchange to Russia working together to solve major } \\
\text { crimes. The parents are detectives and their son and } \\
\text { daughter attend university. The plot involves a death at } \\
\text { the university and the offspring are able to assist their } \\
\text { parents based on insights from their respective } \\
\text { disciplines (law and psychology). Hence, they are } \\
\text { 'intertwined' as a family of crime solvers. }\end{array}$ \\
\hline $\begin{array}{l}\text { Peter (m) } \\
\text { Philip (m) }\end{array}$ & $\begin{array}{l}\text { HIT: Brisbane } \\
\text { (Homicide } \\
\text { Investigation } \\
\text { Team: Brisbane) }\end{array}$ & $\begin{array}{l}\text { Concerns a homicide unit that investigates murders } \\
\text { and missing persons. A female detective 'proves' } \\
\text { herself by providing insights for the rest of the team, } \\
\text { all of whom are male. The program is located in and } \\
\text { around Brisbane with the intention of attracting a local } \\
\text { audience. }\end{array}$ \\
\hline $\begin{array}{l}\text { Naomi (f) } \\
\text { Mona (f) }\end{array}$ & $\begin{array}{l}\text { Behind Closed } \\
\text { Doors }\end{array}$ & $\begin{array}{l}\text { Described as a fictional crime show about domestic } \\
\text { violence. It is based on a squad working out of police } \\
\text { headquarters. This is the only creation that veers } \\
\text { toward documentary, intended by the participants as } \\
\text { 'educational' and informative for the public. }\end{array}$ \\
\hline
\end{tabular}

*Descriptions are based on the participants' summary sheets. 